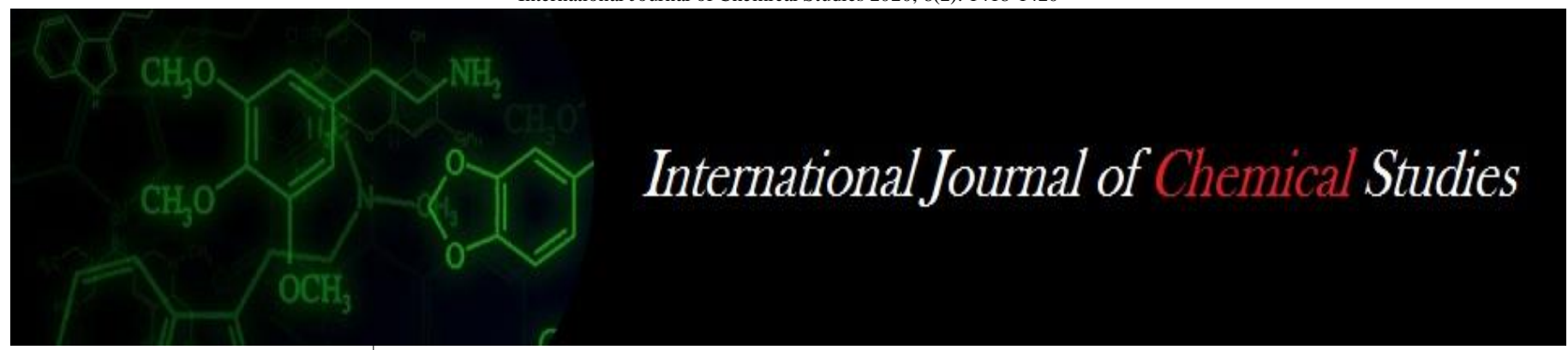

P-ISSN: 2349-8528

E-ISSN: 2321-4902

www.chemijournal.com

IJCS 2020; 8(2): 1418-1420

(C) 2020 IJCS

Received: 08-01-2020

Accepted: 10-02-2020

Surjeet Pandey

Department of Crop Scince

Faculty of Agriculture, Mahatma

Gandhi Chitrakoot Gramoday

Vishwavidyalaya, Chitrakoot,

Uttar Pradesh, India

\section{Madhuri Garg}

Department of Crop Scince

Faculty of Agriculture, Mahatma

Gandhi Chitrakoot Gramoday

Vishwavidyalaya, Chitrakoot,

Uttar Pradesh, India

Dr. SS Singh

Department of Crop Scince

Faculty of Agriculture, Mahatma

Gandhi Chitrakoot Gramoday

Vishwavidyalaya, Chitrakoot,

Uttar Pradesh, India
Corresponding Author:

Surjeet Pandey

Department of Crop Scince

Faculty of Agriculture, Mahatma

Gandhi Chitrakoot Gramoday

Vishwavidyalaya, Chitrakoot,

Uttar Pradesh, India

\section{To study the effect of different growth regulators at various concentration on fruit drop control in mango cv. Lagra}

\author{
Surjeet Pandey, Madhuri Garg and Dr. SS Singh
}

DOI: https://doi.org/10.22271/chemi.2020.v8.i2v.8962

\begin{abstract}
Mango (Mangifera indica L.) is the most important among the tropical fruits of India. It is the premier and choice fruit of India and undoubtedly is one of the best fruits of the world. Mango occupies a preeminent place amongst the fruit crops grown in India and is acknowledged as the king of the fruit of the country. The Langra, also known as Banarasi Langra, is a mango cultivar primarily grown in Banaras, Northern India, Bangladesh and Pakistan. This cultivar retains a greenish tinge while ripening. It is normally harvested during the last half of July. Around 2006, it was known to be gaining popularity on the international market. It is considered suitable for slicing and canning. Fruit drop is the serious problem of central and north India. There is a lot of problematic factor for fruit drop like low stigmatic receptivity, defective perfect flowers (having defective embryo sac development at anthesis), poor pollen transference, occurrence and extent of self-incompatibility, competition between developing fruitlets and drought or lack of irrigation and incidence of insect pest and diseases. NAA is a plant growth regulator. The effect of growth regulator i.e. naphthalene acetic acid (NAA) on fruit drop, yield and quality in mango, cultivar 'Langra' was studied. Full grown mango plants were sprayed with 10, 20, 30 and 40 ppm NAA at different stages of fruit development. It shows the positive response to all yield attribute. 2,4-D is a also plant growth regulator and also applied in 5, 10, 15 and $20 \mathrm{ppm} .3^{\text {rd }}$ plant growth is taken GA3 with $50,100,150$ and $200 \mathrm{ppm}$. And the result shows that the NAA is most suitable for yield attribution.
\end{abstract}

Keywords: Mango cultivar langra, NAA, 2,4-D, GA3

\section{Introduction}

Mango (Mangifera indica L.) is the most important among the tropical fruits of India. It is the premier and choice fruit of India and undoubtedly is one of the best fruits of the world. Mango occupies a pre-eminent place amongst the fruit crops grown in India and is acknowledged as the king of the fruit of the country. Mangoes have been cultivated for an estimated 4000 years in India and active selection of superior cultivars has taken place (Mukherjee, 1972; Singh, 1978). It belongs to family Anacardiaceae and is the native of Indo-Burma region (De Candole, 1904). Besides its delicious taste, excellent flavor and attractive fragrance, it is an excellent source of vitamin A $(6375-20750 \mu \mathrm{g} / 100 \mathrm{~g} \beta$-carotene) and Vitamin C (6.8-38.8 mg /100g) and mineral contents (Chandra and Chandra, 1997) ${ }^{[2]}$.

Mango is very well adapted to tropical and sub-tropical climate and it thrives well in almost all regions of India from sea level to an altitude of $1500 \mathrm{~m}$. Mango can be grown successfully at a temperature between $24^{\circ} \mathrm{C}$ to $27^{\circ} \mathrm{C}$. The tree is hardy in nature and it can endure even the temperature as high as $48^{\circ} \mathrm{C}$. It can be grown successfully in low rainfall area of as low as 25 $\mathrm{cm}$ and as high as $375 \mathrm{~cm}$ per annum. It is gaining more popularity as one of the important dry land horticultural crops. Hence, there is a lot of scope for large scale planting of mango in the vast low rainfall areas of the country provided the temperature and soil are ideal for its growth. Mango is being grown in more than 87 countries of the world but India ranks first in the world with respect to 1.60 million hectares area and 10.78 million tones production (Gandhi, 2012) [3]. India contributes to more than 70 per cent of the total world's production and this offers bright prospects for further boosting exports. Madhya Pradesh is one of the important mangogrowing states of India and the crop occupies an area of 25764 hectare with production of 113801.8 metric tonnes (Anonymous, 2012-13) ${ }^{[1]}$. Most of the area of Madhya Pradesh is rainfed and vast acreage has an immense potential to improve mango production. 
Mango can be used in all the stages of immature, mature and unripe fruits, because of its excellent flavor, attractive fragrance, and beautiful shade of colour, delicious taste and healthful value. Immature and green fruits are used for preparing curries, pickles and chutneys and ripe fruits are utilized in preparing squash, nectar, jam, cereal flakes, custard powder, baby food, mango leather, toffee and several other products.

Mango takes about three months time for fruit set to maturity and ripening. Some varieties may take four months for the same. In the northern region mango is harvested during May to July, while it is November to January in southern region. In South India, the fruits come to harvest earlier by two months as compared to north. Due to multiplicity of cultivars, the harvesting season is spread for over three months. In Madhya Pradesh, ripe mango fruit of North Indian cultivars are available 2-3 weeks earlier, whereas South Indian cultivars are available 2-3 weeks later in the season. This variation has great scope of utilization of mango fruit for export (state and abroad), fresh consumption and processing purpose. Therefore, knowledge of developmental stages of mango fruits is necessary to meet out the demand of standard quality fruits both for processing industry and market supply of the region.

Fruit drop of mango is a serious problem causing heavy losses to the orchardists. Sometimes, 99 per cent crop is lost due to drop of hermaphrodite flowers and immature fruits (Mukherjee, 1949) ${ }^{[5]}$. The intensity of drop is maximum within 15 days after pollination/ anthesis, in which about 6070 per cent hermaphrodite flowers and immature fruit, drop. The second drop (about 30\%) occurs between 28-35 days, when the fruits are at the marble stage. The third drop, which occurs irregularly from 40 days to maturity of fruits is quite low $(3-5 \%)$, but it is important because immature fruits at the advance stage of growth drop during this period.

Several attempts have been made in the past to control fruit drop in mango cultivars by various workers using auxins (NAA, planofix, 2, 4-D, 2, 4, 5-T, and MENA), gibberellins (GA3), cytokinin, growth retardants (alar, cycocel) and other chemicals (urea, sevin, silver nitrate). However, increase in fruit retention with these chemicals varied between 5.75 and 50.00 per cent (Shukla, 2011) ${ }^{[8]}$. Major cause attribute to this phenomenon are lack of pollination, low stigmatic receptivity, defective perfect flowers (having defective embryo sac development at anthesis), poor pollen transference, occurrence and extent of self-incompatibility, competition between developing fruitlets and drought or lack of irrigation and incidence of insect pest and diseases (Singh, 1960). Number of research works have been noticed the performance of different chemicals in mango fruit retention and some of the best chemicals and their concentration are $10 \mathrm{ppm}$ 2, 4-D (Singh et al., 1910), 10-20 ppm NAA (Singh et al., 1994) ${ }^{[10],}$
40 ppm NAA (Gupta and Brahmachari, 2004), 200 ppm GA3 (Rani and Brahmachari, 2013) [7] and 3 per cent urea (Tripathi, 2012), 200 ppm Sevin (Ram and Sirohi, 1909).

\section{Method and materials}

This paper deals with a concise description of the materials used and the techniques adopted during the course of the investigation. The present investigation entitled "Effect of Plant Growth Regulators on Fruit Drop and Physico-Chemical Composition of Mango (Mangifera indica L.) cv. Langra" was conducted at the Department of Crop Sciences, MGCGV, Chitrakoot Satna (M.P.)

\section{Experimental site}

Ten years old mango trees, planted at $10 \times 10 \mathrm{~m}$ spacing were used for experiment, which was carried out at the research field of Horticulture, Tulsi Krashi Vigyan Kendra Ganeewa Rajapur, Dist- Chitrakoot (U.P.) during the year 20014

\section{Choice of variety}

Madhya Pradesh and Uttar Pradesh are reputed for producing early maturing and best quality of Langra mango. Therefore, it was selected for the present investigation.

\section{Selection of trees}

Thirty-nine healthy, vigorous and uniform disease free, bearing trees of about Ten years of age were selected for the experiment. Selected trees were kept under uniform cultural practices, i.e. irrigation, weeding and hoeing etc.

\section{Preparation of solution}

Required quantity of 2, 4-D and GA3 were dissolved in a small quantity of ethyl alcohol but NAA was dissolved in a few drops of $\mathrm{NH} 4 \mathrm{OH}$ to avoid precipitation. Then the final volume was made upto one litre with distilled water. The stock solution of the chemicals was diluted with water for preparing the required strength of the foliar spray. Spraying was done with fixed nozzle having mist droplets with sprayer.

\section{Time of spray}

The spraying was done on 20th February and 5th March 2014 from 8.00 a.m. to 5.00 p.m. on a sunny day. Plant growth regulators in different concentrations were sprayed at pin head stage and marble stage. In all the treatments, solutions were sprayed on panicle/fruit and foliage of the tree.

\subsection{Irrigation}

Experimental trees were irrigated whenever necessary.

\subsection{Observations recorded}

To find out the relative performance of the individual treatment the following characters were recorded:

Table 1.1: Fruit retention per cent as influenced by foliar application of plant growth regulators

\begin{tabular}{|c|c|c|c|c|c|}
\hline \multirow[t]{2}{*}{ Treatments } & \multicolumn{5}{|c|}{ Fruit retention $(\%)$} \\
\hline & 15 DAS & 30 DAS & 45 DAS & 60 DAS & 75 DAS \\
\hline $\begin{array}{l}\text { T0: Without application of plant growth } \\
\text { regulators (control) }\end{array}$ & *35.63a (33.94) & $22.35 \mathrm{a}(14.46)$ & $16.71 \mathrm{a}(8.27)$ & $13.30 \mathrm{a}(5.29)$ & $12.56 \mathrm{a}(4.73)$ \\
\hline T1: 10 ppm foliar application of NAA & 42.65cdef (45.90) & 25.70abc (18.81) & $20.31 \mathrm{~b}(12.05)$ & $17.02 \mathrm{bcd}(8.57)$ & $15.42 \mathrm{bcd}(7.08)$ \\
\hline T2: $20 \mathrm{ppm}$ foliar application of NAA & 42.63cdef (45.87) & $27.71 \mathrm{bc}(21.62)$ & 21.67bcd (13.64) & $16.91 \mathrm{bcd}(8.46)$ & 17.02 bcde $(8.57)$ \\
\hline T3: $30 \mathrm{ppm}$ foliar application of NAA & 44.01def (48.27) & $28.79 \mathrm{c}(23.19)$ & $23.53 \mathrm{~cd}(15.94)$ & $19.78 \mathrm{ef}(11.45)$ & $19.41 \mathrm{ef}(11.04)$ \\
\hline T4: $40 \mathrm{ppm}$ foliar application of NAA & $45.51 \mathrm{f}(50.89)$ & $34.86 \mathrm{~d}(32.67)$ & $30.34 \mathrm{e}(25.51)$ & $25.38 \mathrm{~g}(18.37)$ & $24.86 \mathrm{~g}(17.67)$ \\
\hline T5: $5 \mathrm{ppm}$ foliar application of $2,4-\mathrm{D}$ & $43.57 \mathrm{def}(47.51)$ & $26.23 \mathrm{abc}(19.53)$ & $21.02 \mathrm{bc}(12.87)$ & $17.67 \mathrm{cde}(9.21)$ & $17.19 \mathrm{de}(8.73)$ \\
\hline T6: $10 \mathrm{ppm}$ foliar application of 2, 4-D & $(47.51) 46.27 \mathrm{f}$ & $(19.53) 29.16 \mathrm{c}$ & (12.87) $23.84 \mathrm{~cd}$ & $(9.21) 20.43 \mathrm{f}$ & (8.73) 19.80f \\
\hline T7: $15 \mathrm{ppm}$ foliar application of 2, 4-D & 41.68bcde (44.22) & $27.63 \mathrm{bc}(21.51)$ & $23.67 \mathrm{~cd}(16.12)$ & $17.85 \mathrm{cde}(9.40)$ & 17.11 cde $(8.65)$ \\
\hline
\end{tabular}




\begin{tabular}{|c|c|c|c|c|c|}
\hline T8: $20 \mathrm{ppm}$ foliar application of 2, 4-D & $39.83 \mathrm{bc}(41.02)$ & $25.20 \mathrm{abc}(18.13)$ & $20.86 \mathrm{bc}(12.68)$ & $15.06 \mathrm{ab}(6.75)$ & $14.60 \mathrm{ab}(6.36)$ \\
\hline T9: $50 \mathrm{ppm}$ foliar application of GA3 & $38.74 \mathrm{ab}(39.16)$ & $26.22 \mathrm{abc}(19.52)$ & $21.61 \mathrm{bcd}(13.56)$ & $18.15 \mathrm{de}(9.70)$ & $18.06 \mathrm{ef}(9.61)$ \\
\hline T10: $100 \mathrm{ppm}$ foliar application of GA3 & $45.01 \mathrm{ef} \mathrm{(50.02)}$ & $28.38 \mathrm{c}(22.59)$ & $24.20 \mathrm{~d}(16.80)$ & $19.21 \mathrm{ef}(10.83)$ & $18.30 \mathrm{ef}(9.86)$ \\
\hline T11: $150 \mathrm{ppm}$ foliar application of GA3 & $41.00 \mathrm{bcd}(43.04)$ & $25.49 \mathrm{abc}(18.52)$ & $20.97 \mathrm{bc}(12.81)$ & $15.94 \mathrm{bc}(7.54)$ & $15.40 \mathrm{bcd}(7.05)$ \\
\hline T12: $200 \mathrm{ppm}$ foliar application of GA3 & $40.71 \mathrm{bcd}(42.54)$ & $23.86 \mathrm{ab}(16.36)$ & $19.52 \mathrm{ab}(11.50)$ & $15.36 \mathrm{ab}(7.02)$ & $14.68 \mathrm{abc}(6.42)$ \\
\hline
\end{tabular}

Table 1.2: Fruit drop per cent as influenced by foliar application of plant growth regulators

\begin{tabular}{|c|c|c|c|c|c|}
\hline \multirow[t]{2}{*}{ Treatments } & \multicolumn{5}{|c|}{ Fruit drop (\%) } \\
\hline & 15 DAS & 30 DAS & 45 DAS & 60 DAS & 75 DAS \\
\hline $\begin{array}{l}\text { T0: Without application of plant growth } \\
\text { regulators (control) }\end{array}$ & $* 54.37 f(66.06)$ & $67.64 c(85.53)$ & $73.29 \mathrm{c}(91.73)$ & 76.70d (94.71) & $77.43 \mathrm{c}(95.26)$ \\
\hline T1: 10 ppm foliar application of NAA & 47.36abcde (54.11) & $64.30 \mathrm{bc}(81.19)$ & $70.59 b c(88.96)$ & $74.42 \mathrm{bcd}(92.79)$ & $75.25 b c(93.52)$ \\
\hline T2: $20 \mathrm{ppm}$ foliar application of NAA & $47.27 \mathrm{abcde}(54.04)$ & $62.29 \mathrm{bc}(78.38)$ & $68.33 b c(86.36)$ & $73.79 b c d(92.21)$ & $73.97 \mathrm{bc}(92.37)$ \\
\hline T3: $30 \mathrm{ppm}$ foliar application of NAA & 45.99abcd (51.72) & $61.21 \mathrm{~b}(76.81)$ & $66.80 \mathrm{~b}(84.48)$ & $70.66 \mathrm{abc}(89.03)$ & $71.18 \mathrm{ab}(89.59)$ \\
\hline T4: $40 \mathrm{ppm}$ foliar application of NAA & 44.49abc (49.1) & $55.10 \mathrm{a}(67.26)$ & $59.65 \mathrm{a}(74.47)$ & $65.37 \mathrm{a}(82.63)$ & $65.84 \mathrm{a}(81.92)$ \\
\hline T5: $5 \mathrm{ppm}$ foliar application of 2, 4-D & 46.41abcd (52.45) & $64.20 \mathrm{bc}(81.08)$ & $68.81 \mathrm{bc}(86.93)$ & 72.72bcd (91.18) & $73.35 b c(91.79)$ \\
\hline T6: $10 \mathrm{ppm}$ foliar application of 2, 4-D & $43.73 \mathrm{a}(47.78)$ & $60.84 \mathrm{~b}(76.26)$ & $66.50 \mathrm{~b}(84.1)$ & $69.97 \mathrm{ab}(88.27)$ & $70.86 \mathrm{ab}(89.25)$ \\
\hline T7: $15 \mathrm{ppm}$ foliar application of 2, 4-D & 48.32bcde (55.78) & $62.37 \mathrm{bc}(78.49)$ & $66.33 b(83.88)$ & 72.44bcd (90.9) & 72.98bc (91.43) \\
\hline T8: $20 \mathrm{ppm}$ foliar application of 2, 4-D & $50.17 \mathrm{e}(58.97)$ & $65.09 \mathrm{bc}(82.26)$ & $69.13 b c(87.31)$ & 74.93bcd (93.24) & $75.63 \mathrm{bc}(93.84)$ \\
\hline T9: $50 \mathrm{ppm}$ foliar application of GA3 & 51.26ef $(60.84)$ & $64.35 \mathrm{bc}(81.26)$ & $68.71 b c(86.82)$ & 72.64bcd (91.08) & $73.10 \mathrm{bc}(91.55)$ \\
\hline T10: $100 \mathrm{ppm}$ foliar application of GA3 & $44.99 \mathrm{abc}(49.98)$ & $61.61 \mathrm{~b}(77.39)$ & 65.80ab (83.2) & 71.35 bcd $(89.77)$ & $72.25 b c(90.71)$ \\
\hline T11: $150 \mathrm{ppm}$ foliar application of GA3 & 49.00cde (56.96) & $64.51 b c(81.48)$ & 69.03bc (87.19) & $74.05 \mathrm{bcd}(92.45)$ & $74.50 \mathrm{bc}(92.86)$ \\
\hline T12: $200 \mathrm{ppm}$ foliar application of GA3 & $49.29 \mathrm{de}(57.46)$ & $66.49 \mathrm{bc}(84.09)$ & $70.18 b c(88.5)$ & $75.70 \mathrm{~cd}(93.9)$ & $76.09 \mathrm{bc}(94.22)$ \\
\hline
\end{tabular}

\section{Result and Conclusion \\ Fruit retention}

The application of different concentration of plant growth regulators at pin head and marble stage significantly affected the fruit drop of mango. In present investigation, the maximum fruit retention percentage was found under $10 \mathrm{ppm}$ foliar application of 2, 4-D at 15 days after spray and foliar application of 40 ppm NAA increased fruit retention at 30, 45, 60 and 75 days after spray. Minimum fruit retention percentage was found under control at all stages.

\section{Fruit drop}

The foliar application of $10 \mathrm{ppm} \mathrm{2,4-D} \mathrm{was} \mathrm{found} \mathrm{more}$ effective in reducing the fruit drop at 15 days after spray and foliar application of $40 \mathrm{ppm}$ NAA was found more effective in reducing the fruit drop at 30, 45, 60 and 75 days after spray. Maximum fruit drop percentage was found under control at all stages.

Conclusions drawn on the basis of results obtained from the present investigation are as under: The yield-contributing characters, foliar application of 40 ppm NAA at pin head and marble stage of fruit development increased the fruit retention, reduced the fruit drop and gave maximum number of fruits as well as total yield. Length and width of fruits, average fruit weight, volume and pulp were improved with the foliar application of $40 \mathrm{ppm}$ NAA. While, stone weight and peel weight was reduced with the foliar application of 150 ppm GA3 and 15 ppm foliar application of 2, 4-D.

Qualitative characters like TSS and ascorbic acid improved with foliar application of $150 \mathrm{ppm}$ GA3. Whereas, reducing sugar increased with $40 \mathrm{ppm}$ foliar application of NAA. While, acidity of fruits was reduced with the foliar application of $10 \mathrm{ppm} 2$, 4-D.

It can also be concluded that the foliar application of $40 \mathrm{ppm}$ NAA, 150 ppm GA3, 10 and 15 ppm 2, 4-D were found to be optimum concentration by which yield and physico-chemical composition of fruits can be significantly influenced.

\section{References}

1. Anonymous. Directorate of Horticulture. Government of Madhya Pradesh, Bhopal, 2012-13.
2. Chandra A, Chandra A. Production and Postharvest Technology of Fruits, NBS Pub. \& Distributions, Bikaner, India (c. f. Hort. CD), 1997.

3. Gandhi GP. Export prospects of mangoes and mangobased products from India. Plant Horti. Tech. 2012; $5(2): 37$.

4. Gupta RK, Brahmachari VS. Effect of foliar application of urea, potassium nitrate and NAA on fruit retention, yield and quality of mango cv. Bombai. Orissa J. Hort. 2011; 32(2):7-9.

5. Mukherjee SK. The mango and its relatives. Sci. and Cult., (c. f. Indian J. Hort.). 1949; 40(15):5-9.

6. Ram S, Sirohi SC. Studies on fruit drop in mango. Mango workers meeting, research reports on mango. Panaji, Goa. 2009; 2-5:432-433, 1979.

7. Rani R, Brahmachari VS. Effect of growth substances and calcium compounds on fruit retention, growth and yield of Amrapali mango. Orissa J. Hort. 2013; 32(1):1518.

8. Shukla AK. Effect of plant growth regulators, NAA and 2, 4-D on control of fruit drop in mango (Mangifera indica L.) varieties Langra and Dashehari. M.Sc. (Ag.) thesis Indira Gandhi Agricultural University, Raipur (C.G.), 2011.

9. Singh AR. Effect of foliar sprays of nitrogen and growth regulators on the physico-chemical composition of mango (Mangifera indica L.). Plant Science, (c. f. Hort. CD). 2010; 8:75-81.

10. Singh JN, Singh DK, Chakraborty D. Effect of urea and NAA on fruit retention and physico-chemical composition of mango (Mangifera indica L.) cv. Langra. Orissa. J. Hort. 1994; 22(1-2):26-30.

11. Tripathi PC. Effect of thiourea, potassium nitrate and urea on new shoot production and fruiting in Dashehari mango. Prog. Hort. 2012; 34(2):268-270. 